\title{
DOBRO W KONTEKSTACH III RZESZY. REFLEKSJA WSTĘPNA
}

Dwudzieste stulecie, naznaczone tak bardzo przez totalitaryzm różnorakiej proweniencji, pozostaje czasem, w którym doświadczenie graniczne ${ }^{1}$ nabrało charakteru powszechnego. Zjawisko to dotykało większość terenów, które amerykański historyk Timothy Snyder określił jako „skrwawione ziemie"2 ${ }^{\prime 2}$ Świat wartości ulegał przetasowaniom i zmianom, które uwidoczniły się zarówno w hitlerowskich Niemczech, jak i sowieckim imperium kierowanym przez Stalina.

Tylko pobieżny wgląd $\mathrm{w}$ masowo publikowane w nazistowskich Niemczech słowniki i leksykony nie pozostawia złudzeń: słowa objaśniające rzeczywistość w kategoriach ogólnie przyjmowanych pojawiają się w hasłach $\mathrm{i}$ artykułach najczęściej $\mathrm{w}$ nowych konotacjach, dostosowanych do coraz bardziej "brunatnej” codzienności. Zjawisko to dokładnie opisał Viktor Klemperer, dokumentując tworzenie się lingua tertii imperii ${ }^{3}$, którego kreowany językowy obraz świata ${ }^{4}$ wykazywał dwie konstytutywne cechy: albo budowanie zupełnie nowych określeń dla potrzeb wprowadzania w czyn zasad nazistowskiej rewolucji, albo rewaloryzację dostępnego wokabularza

\footnotetext{
${ }^{1}$ Por. J. Leociak, Doświadczenie graniczne. Studia o dwudziestowiecznych formach reprezentacji, Warszawa 2009

2 T. Snyder, Skrwawione ziemie. Europa między Hitlerem a Stalinem, tłum. B. Pietrzyk, Warszawa 2011.

${ }^{3}$ Por. V. Klemperer, LTI, Notatnik filologa, tłum. J. Zychowicz, Kraków - Wrocław 1983.

${ }^{4}$ Por. J. Bartmiński, Jezykowe podstawy obrazu świata, Lublin 2006.
} 
na rzecz ewoluującej i doprecyzowywanej doktryny tworzącej podstawy funkcjonowania niemieckiego państwa ${ }^{5}$. Wywołany w 1939 roku agresją na Polskę konflikt zbrojny wprowadził do rozbudowanej w latach 1933-1939 nowomowy nazistowskiej bardzo wiele dodatkowych elementów, wynikających $\mathrm{z}$ sytuacji na froncie i postępów $\mathrm{w}$ transferze nazistowskiej ideologii na terenach okupowanych, które wręcz błyskawicznie implementowano do różnych mediów ${ }^{6}$. Na przykład opublikowany wiosną 1940 roku kieszonkowy leksykon Brockhausa noszący podtytuł Słownik wydarzeń bieżacych zawiera obszerne hasła, opatrzone tablicami graficznymi bądź materiałem fotograficznym, dotyczące następującej problematyki: kampania przeciwko Polsce (Polenfeldzug), niemiecki Wschód i jego cechy charakterystyczne (np. katedra gnieźnieńska jako emanacja niemieckiego gotyku etc.), sytuacja prawna terenów przejętych w wyniku działań okupacyjnych (z perspektywy niemieckiej armii pojmowanych jako „akcja prewencyjna w Danii i Norwegii"7) oraz wiele innych. Lektura hasła poświęconego Żydom pozwala przyjąć założenie, że czytelnik jest już dobrze zorientowany w nazistowskim systemie kryteriów rasowych, wykluczających Żydów z realizowanej wspólnoty narodowej (Volksgemeinschaft) 8 , i potrzebuje tylko najaktualniejszej wiedzy na ten temat. Artykuł Obrona przed Żydami (Judenabwehr) ${ }^{9}$ przedstawia szczegółowo bieżącą sytuację prawną w Niemczech oraz informuje,

${ }^{5}$ Por. C. Schmitz-Bernig, Vokabular des Nationalismus, 2., durchgesehene und überarbeitete Auflage, Berlin - New York 2007.

${ }^{6} \mathrm{Nie}$ chodzi tu bynajmniej o wszechobecną propagandę, co raczej publikacje znajdujące się na półkach w każdej szkolnej bibliotece bądź dodawane do kompletu podręczników, których druk i dystrybucję całkowicie pokrywało państwo.

7 Por. Taschen-Brockhaus, Wörterbuch zum Zeitgeschehen. b.a. Brockhaus, Leipzig 1940, s. 46-52, zdjęcia z okupowanej Polski, s. 80-81; sytuacja w Skandynawii, s. 191-192.

8 Koncepcja wspólnoty narodowej (Volksgemeinschaft), oparta na docelowej jedności narodu i biologicznie pojmowanej rasy, jest obecnie najlepszym sposobem opisu niemieckiego społeczeństwa i jego transformacji w latach 1933-45. Podsumowaniem badań nad tym zagadnieniem był międzynarodowy kongres „Volksgemeinschaft? Konstruktion, gesellschaftliche Wirkungsmacht und Erinnerung vor Ort", który obradował w dniach od 25.06 do 27.06.2015 roku w Hanowerze. Wygłoszone referaty pokazały, że jest to podejście umożliwiające badania historii społecznej zarówno w skali makro- jak i mikro. Mechanizm tworzenia Volksgemeinschaft opisuję np. z perspektywy osobistych doświadczeń Edyty Stein w artykule: M. Grzywacz, Pole eksperymentalne Warthegau. Glossy do pewnych wypowiedzi Edyty Stein, "Zeszyty Naukowe Centrum Badań im. Edyty Stein" 2014, nr 11: Fenomen Edyty Stein. Das Phänomen Edith Stein, red. M. Bernhardt, A. Grzegorczyk, M. Grzywacz, K. Machtyl, s. 185-197. W mikroskali przybliżam tę problematykę na przykładzie małego, prowincjonalnego miasteczka Lörrach na granicy niemiecko-szwajcarskiej i historii tragicznego związku Niemki i polskiego robotnika przymusowego w tekście: Osaczeni przez Volksgemeinschaft. Polsko-niemiecka relacja o miłości o osamotnieniu w III Rzeszy, "Zeszyty Naukowe Centrum Badań im. Edyty Stein” 2014, nr 12: Wobec samotności, red. A. Kaczmarek, A. Kulig, K. Machtyl, s. 221-236.

${ }^{9}$ Por. Taschen-Brockhaus, op. cit., s. 137-138. 
że zasady te stanowią podstawę "narodowosocjalistycznej moralności” (Sittlichkeit $)^{10}$. Mamy tu do czynienia nie tyle z systemem totalitarnego państwa, co raczej stworzeniem szerokiego konsensusu społecznego rządzących i rządzonych, którego lepiszczem byl, z jednej strony, wszechobecny antysemityzm ${ }^{11}$ i szerząca się nienawiść wobec obcych, z drugiej zaś - sam Adolf Hitler, którego większość przyjęła za gwaranta odnowy niemieckiego społeczeństwa ${ }^{12}$.

Robert Gellately proponuje podział historii Trzeciej Rzeszy na trzy etapy ${ }^{13}$. W każdym z nich poparcie Niemców dla rządów hitlerowskich wyglądało inaczej. Pierwszą fazę stanowiły lata 1933-193814. W tym czasie tworzyła się wśród ludności opinia o powrocie Niemiec do stanu normalnego. Osiągnięto stabilność, zwiększono zatrudnienie. Nazyfikacja następowała powoli, a tworzenie wspólnoty narodowej odbywało się za przyzwoleniem społeczeństwa. Media informowały oficjalnie o tworzeniu obozów koncentracyjnych, które miały zapobiec fali przemocy i rozwojowi przestępczości ${ }^{15}$. Medialny obraz Republiki Weimarskiej jako kraju bardzo niestabilnego przekształcił się w wizerunek kraju, w którym zaczynało rządzić prawo. Na przykład w 1936 roku większość gazet niemieckich przekazywała informacje, iż obozy koncentracyjne spełniały swoje reedukacyjne zadanie. Propaganda lansowała obraz porządnych Niemiec i wykorzystywała do tego najróżniejsze sposoby - zapraszano np. dziennikarzy z zagranicy do odbycia podróży, w trakcie których zwiedzano także przygotowane odpowiednio obozy ${ }^{16}$.

Budowa wspólnoty narodowej nie byłaby możliwa bez systemu donosicielstwa i szpiclowania. Praktyczne poparcie dla rządu i jego działań oraz posiadanie tak znaczących wpływów i tak dużego stopnia zaufania społecznego sprawiało, że władze informowano o wszystkim, co mogło „budzić podejrzenie" 17 . Nie był to kraj uciemiężonej terrorem większości, lecz raczej taki, w którym większość przez swoje postępowanie przyczyniała się do stopniowej i konsekwentnej budowy nowych, innych Niemiec. Cezurę

10 Ibidem.

11 Np. M. Wildt, Volksgemeinschaft als Selbstermächtigung. Gewalt gegen Juden in der deutschen Provinz 1919-1939, Hamburg 2007, s. 2-3.

12 R. Gross, W. Konitzer, Geschichte und Ethik. Zum Fortwirken der nationalsozialistischen 'Mo$\mathrm{ral}^{\prime}$, „Mittelweg” 1999, No. 36, H. 4, s. 44-67.

13 R. Gellately, Hingeschaut und weggesehen. Hitler und sein Volk. Aus dem Amerikanischen von Holger Fliessbach, Stuttgart - München 2002.

14 R. Gellately, op. cit, s. 359.

15 Ibidem, s. 77-101.

16 Ibidem, s. 87-89.

17 Ibidem, s. 357. 
otwierającą następny etap w historii III Rzeszy stanowił wybuch wojny18, który zradykalizował brunatną rewolucję i - jak pokazał przytoczony przykład z popularnego leksykonu - przeniósł zadanie budowy wspólnoty na tereny okupowane, nie zatracając przy tym niczego z początkowego impetu rozwoju nazizmu, a nawet go wzmacniając. Za ostatnią fazę tej historii można uznać ostatnie pół roku wojny ${ }^{19}$, choć zdaje się, że można ją cofnąć nieco wcześniej, aż do nieudanego zamachu na Hitlera 20 lipca 1944 roku, po którym nastąpiło pierwsze przegrupowanie $\mathrm{w}$ rządach nazistowskich i bezpośrednim otoczeniu Führera. Takich przetasowań będzie do końca wojny jeszcze więcej.

\section{Raport z wnętrza nazistowskiej wspólnoty narodowej. Dietricha Bonhoeffera ${ }^{20}$ Sprawozdanie na poczatek roku $1943^{21}$}

Czternastostronicowy maszynopis Dietricha Bonhoeffera, dedykowany przyjaciołom - Eberhardowi Bethge, Hansowi von Dohnanyi i Hansowi Osterowi - nosił znamienny podtytuł Po dziesięciu latach i miał charakter poufny. Tekst ów miał, zgodnie z intencją autora, "przedstawić rezultaty wspólnego doświadczenia na płaszczyźnie tego, co ludzkie"22. Centralnym pytaniem, na które Bonhoeffer starał się znaleźć odpowiedź, pozostawała

18 Ibidem. s. 361.

${ }^{19}$ Ibidem.

${ }^{20}$ Dietrich Bonhoeffer (1906-1945), teolog ewangelicki, habilitował się z teologii systematycznej na uniwersytecie w Berlinie. Od 1931 r. zaangażowany w ruch ekumeniczny. Zdeklarowany przeciwnik narodowego socjalizmu, potępiający politykę nazistów wobec Żydów. Pozbawiony w 1936 roku prawa do nauczania (odebrano mu habilitację), w 1938 roku zakazano mu przebywania na terenie Berlina i Brandenburgii. Jeden z głównych twórców Kościoła Wyznającego (Bekennende Kirche) - nurtu sprzeciwiającego się implementacji ideologii nazistowskiej do doktryny Kościołów ewangelickich. Od połowy roku 1939 roku Bonhoeffer pozostawał w kontakcie z politycznym ruchem oporu, później włączył się aktywnie w pracę wywiadu wojskowego. Uwięziony w 1943 r., oskarżony w 1944 r. o wspieranie zamachowców z 20 lipca 1944 r., został osadzony w obozach koncentracyjnych, a następnie stracony 9 kwietnia 1945 r. we Flossenbürgu. Por. B. Milerski, Dietrich Bonhoeffer. Teolog chrześcijaństwa świeckiego, [w:] Leksykon wielkich teologów XX/XXI wieku, Warszawa 2003, s. 30-39. Najnowsza i poznawczo bardzo wartościowa biografia Bonhoeffera ukazała się przed rokiem w USA: Ch. Marsh, Strange Glory. A Life of Dietrich Bonhoeffer, New York 2014.

${ }^{21}$ D. Bonhoeffer, Rechenschaft an der Wende zum Jahr 1943, [w:] Dietrich Bonhoeffer Gesammelte Werke, Bd. 8: Widerstand und Ergebung, Gütersloh 1998, s. 19-39. Jeśli nie zaznaczono inaczej, wszystkie tłumaczenia pochodzą od autorki artykułu.

22 Ibidem, s. 20. 
kwestia użyteczności społecznej ludzi podzielających poglądy jego i kręgu przyjaciół, którzy przyłączyli się do ruchu oporu wobec nazistów:

Byliśmy milczącymi świadkami złych czynów, wiele przeszliśmy, nauczyliśmy się sztuki mówienia nie wprost, doświadczenie nauczyło nas nie ufać ludziom. Byliśmy winni im często jasną odpowiedź i czystą prawdę. Zniszczyły nas męczące konflikty, staliśmy się nieco cyniczni - czy nas w ogóle potrzebują?23.

Bonhoeffer formułuje zdania w liczbie mnogiej - „my” to maleńkie, zatomizowane grupy, przeciwstawiające się wszechogarniającej wspólnocie narodowej, wywodzące się głównie z elit intelektualno-wojskowych.

Okres 1933-1942 Bonhoeffer określił mianem czasów „wielkiej maskarady zła", którą trudno wytrzymać24. Pojęcie zła (das Böse $)^{25}$ pojawia się w tekście ewangelickiego teologa kilkakrotnie, za każdym razem jako opis destrukcyjnej siły, mocy zagrażającej życiu i niszczycielskiej. Bonhoeffer używa go w absolutnym znaczeniu, któremu przeciwstawić można tylko dobro. Niemczyzna, w odróżnieniu od innych języków europejskich, wypracowała bardzo zróżnicowane pola semantyczne opisujące zarówno dobro, jak i $z^{2}{ }^{26}$. Od wczesnych faz rozwoju języka niemieckiego (i innych języków germańskich ${ }^{27}$ łacińskiemu słowu bonum odpowiadają dwa określenia: 1. das $G u t^{28}$ - dobro jako posiadana rzecz stanowiąca własność, którą rozumieć można także w liczbie mnogiej, np. dobra ziemskie, oraz 2. das Gute - dobro przynależące do porządku nadnaturalnego, będące dobrem wiecznym (bonum aeternum). Z drugiego źródłosłowu wywodzi się także niemieckie Gott, czyli Bóg, którego konotacja (oraz możliwość użycia, bądź nie, liczby mnogiej) uzależniona jest od konkretnej religii (mono- bądź politeistycznej). Najwyższe Dobro (das Höchste Gut) to synonim Boga, spotykany w języku teologii i mistyki29. Das Gute - czyli dobro w sensie absolutnym - oznacza tajemnicę,

\footnotetext{
23 Ibidem.

24 Ibidem.

${ }^{25}$ M. Weber, Dietrich Bonhoeffer von A bis Z. Sein Denken und Reden, sein Predigen und Beten in Schlagworten erschlossen, Gütersloh 2010, s. 24-25.

${ }^{26}$ Wszystkie uwagi dotyczące etymologii pojęc „,dobro” i „zło” w języku niemieckim opieram na klasycznym, będącym jak do tej pory nie do zastąpienia, słowniku Jakuba i Wilhelma Grimmów, dostępnym od 2013 roku w wersji elektronicznej: Deutsches Wörterbuch von Jacob und Wilhelm Grimm, 16 Bände in 32 Teilbänden, Leipzig 1854-1961, Quellenverzeichnis Leipzig 1971, Online-Version mit einer pdf-Ausgabe, http://woerterbuchnetz.de/DWB/ (dostęp

27 Ibidem.

${ }^{28} \mathrm{http}$ / / woerterbuchnetz.de/DWB/?sigle=DWB\&mode=Vernetzung\&lemid=GG32832\# XGG32832, (dostęp 30.05.2015 r.).

${ }^{29}$ Ibidem.
} 15.05.2015 r.). 
wręcz misterium dobra, towarzyszące człowiekowi nieustannie i dające się poznać w biblijnej narracji o prapoczątkach, gdy Bóg widział, że dzieło stworzenia, którego dokonal, jest dobre ${ }^{30}$.

Innym określeniem oznaczającym dobro, także dobro wspólne, jest das Wolhl31. Odpowiada ono także łacińskiemu bonum, lecz pokrywa się z pojęciami felicitas i prosperitas, czyli ze stanem, który można by doprecyzować jako trwanie jednostki i wspólnoty w szczęśliwości i dobro-bycie (nie tylko ekonomicznym), jako dobrostan.

Podobnie skomplikowana sytuacja zachodzi, gdy odnosimy się do treściowego zakresu określającego zło: to nie tylko destrukcyjne i śmiercionośne principium określane słowem das Böse, lecz także das Übel ${ }^{32}$ - zło rozumiane jako rezultat niedobrego czynu, postępowania przeciwstawiającego się zasadom uznawanym przez daną wspólnotę jako normatywnie dobre. W sensie teologicznym ${ }^{33}$ jego zakres znaczeniowy zbliża się do słowa der Sünde („grzech"), oznaczającego postępowanie złe ze względu na religię i wynikający z niej katalog norm i zachowań ${ }^{34}$.

Użytą przez Dietricha Bonhoeffera metaforę „wielkiej maskarady zła” (die grosse Maskerade des Bösen) możemy dokładniej prześledzić, zwłaszcza iż autor precyzyjnie określa jej cechy i podaje podstawowe wyróżniki. Jak przystało na maskaradę, mamy do czynienia z przebierańcami, których właściwą twarz możemy zobaczyć po zdjęciu maski. Nie nazywając dokładnie i po imieniu (musimy sobie zdać sprawę z ostrożności formułowanych sądów ze względu na okoliczności zewnętrzne) poszczególnych podmiotów zaangażowanych $\mathrm{w}$ tworzenie korowodu przebierańców, Bonhoeffer zauważa, że owa maskarada to nic innego, jak całkowita zmiana dotychczasowego porządku etycznego. Wszystkie zasady postępowania uległy centryfugalnemu "rozproszeniu”35. Zło (das Böse) przebrało się za dobre czyny (Wohltaten) i powołując się na sprawiedliwość społeczną oraz konieczność historyczną, mami ludzi swoim światłem ${ }^{36}$. Ostatnie dziesięć lat, jak pisze Bonhoeffer, stanowi czas, w którym sumienie nie potrafi się odnaleźć, nie

${ }^{30}$ Ibidem. Por. także Księga Rodzaju, prehistoria biblijna, Rdz. 1,1-11,9.

${ }^{31}$ www.http:// woerterbuchnetz.de/DWB/?sigle=DWB\&mode=Vernetzung\&lemid=GW 24778\#XGW24778, (dostęp: 30.05.2015 r.)

$32 \mathrm{http}$ / / woerterbuchnetz.de/DWB/?sigle=DWB\&mode=Vernetzung\&lemid=GU00008\# XGU00008, (dostęp 25.06.2015 r.).

33 J.B. Hygen, Böse, das, [w:] Theologische Realenzyklopädie (TRE), Bd. 2, hrsg. von B. Müller, Berlin - New York 1973, s. 20-24.

${ }^{34}$ Ibidem, s. 24.

35 D. Bonhoeffer, op. cit., s. 20.

${ }^{36}$ Ibidem, s. 21. 
jest $\mathrm{w}$ stanie rozpoznać tego, co dobre, także w sensie społecznym ${ }^{37}$. Sumienie ${ }^{38}$, wewnętrzny czynnik wspomagający jednostkę $w$ rozeznaniu między dobrem a złem, uległo $\mathrm{w}$ tym czasie zastraszeniu, lecz aby nie poddać się całkowicie rozpaczy, okłamuje samo siebie ${ }^{39}$. Obserwując swoje otoczenie, teolog odnotowal, że Niemcy przez wiele wieków nauczyli się postępować pokornie i podążać za rozkazami, lecz nie potrafią odnieść się do wolności, o której istnieniu przypomniał im na przykład Marcin Luter, i występując przeciwko kościelnym władzom zwierzchnim, wyłączają swoje sumienie ${ }^{40}$. Niemcy, zdaniem Bonhoeffera, zatracili także zdolność do zachowania odwagi cywilnej w sytuacjach, która by od nich tego wymagała ${ }^{41}$.

Projekt narodowego socjalizmu wspierany był przez szerokie masy ${ }^{42}$, które traktowały go w kategoriach zbiorowego sukcesu. Także do tego entuzjazmu, który w trakcie działań wojennych był podtrzymywany i odgórnie sterowany, odniósł się Bonhoeffer w swojej refleksji: jeśli sukces bierze się ze złych czynów, które moralnie trzeba zdyskwalifikować, to dobro (das Wohl) będące jego rezultatem nie będzie nigdy dobrem właściwym, lecz emanacją maskarady zła ${ }^{43}$.

Pisząc te słowa, Bonhoeffer zdawał sobie sprawę, jak bardzo niewielu rodaków podziela jego poglądy - w obliczu masowego poparcia, jakie okazywano nazistom, uważał, że nie należy służyć zwycięzcom, którzy piszą historię, lecz przeciwstawić się im ze względu na odpowiedzialność wobec następnych pokoleń: „Nie jest ważne, czy będzie mnie stać na to, abym heroicznie się wycofał $\mathrm{z}$ tej całej afery, ale ważne jest, aby pokolenia następujące po nas mogły żyć dalej" 44 .

Lecz jak można odtworzyć relacje międzyludzkie, jeśli zostały tak zachwiane, iż nikomu nie można było zaufać? Amerykański badacz Barrington Moore Junior zauważył, że „warunkiem wstępnym dysydenckiego zachowania jest stworzenie przez społeczeństwo nisz względnego bezpieczeństwa, w których niezadowoleni lub uciskani mogli się spotykać i przygotować swoje działanie" 45 . Inwigilacja, szpiclowanie i donosicielstwo, dotykające także bezpośrednich relacji rodzinnych - zdarzało się, że rodzeństwo pisało na

37 Ibidem, s. 22.

38 Por. także hasło das Gewissen („sumienie”), w: M. Weber, op. cit., s. 71.

${ }^{39}$ D. Bonhoeffer, op. cit., s. 22.

${ }^{40}$ Ibidem, s. 24

${ }^{41}$ Ibidem.

${ }^{42}$ R. Gross, W. Konitzer, op. cit., s.48.

${ }^{43}$ D. Bonhoeffer, op. cit., s. 37.

${ }^{44}$ Ibidem, s. 25.

45 B. Moore Jr., Injustice: The Social Bases of Obedience and Revolt, [cyt. za:] R. Gellately, op. cit., s. 438-439. 
siebie donosy i zostawiało je w skrzynce pocztowej tajnej policji46 - sprawiły, że niezwykle trudno było wytworzyć warunki, które pozwoliłyby na powstawanie i działanie dysydenckich ruchów oporu i sprzeciwu.

Aby społeczności zapewnić trwanie, należy - w opinii teologa - odrzucić postępowanie tak typowe dla nowego społecznego porządku: ludźmi nie należy pogardzać, pomiatać nimi; każdy człowiek ma swoją godność i jedynym środkiem przywrócenia prawdziwych relacji międzyludzkich jest zdolność do okazywania najwyższego dobra (das Höchste Gut), jakim jest miłość47. Jednym $\mathrm{z}$ najważniejszych postulatów sformułowanych przez Bonhoeffera na kartach tego maszynopisu jest wezwanie do współcierpienia, współodczuwania „z braćmi, którzy odczuwają na własnej skórze”48, co znaczy być prześladowanym ${ }^{49}$.

Doświadczenie rzeczywistości w nazistowskim projekcie społecznym oznaczało dla osób takich jak Bonhoeffer liczenie się z "mocą okoliczności zewnętrznych, które zmuszą nas do tego, że zaprzestaniemy się troszczyć o dzień następny"50, a także z ryzykiem utraty życia ${ }^{51}$. „Wielka maskarada zła" zakryła dobro (das Gute) całkowicie i dlatego trudno, jak pisze Bonhoeffer, znaleźć tę „wąziutką ścieżynę, która nas z tego gąszczu ostatecznie wyprowadzi" 52 .

Kroplami drążącymi skałę, bądź światełkami w tunelu, były rozproszone po całych Niemczech niewielkie grupy, które najczęściej pracą intelektualną, lekturami, dyskusjami, podejmowały próbę wejścia na ową ścieżynę, która mogła wywieźć błądzących z takiego stanu. Działanie subwersywne miało docelowo doprowadzić do procesu zrywania masek, przerwania korowodu zła, który przekształcił się $\mathrm{w}$ amok wojny totalnej. Ryzyko było znaczne denuncjacja i postawienie zarzutu o osłabianie siły obronnej (Wehrkraftzersetzung) wspólnoty narodowej kończyło się najczęściej obozem koncentracyjnym bądź też szybko wykonywaną karą śmierci53. Takich zaangażowanych,

\footnotetext{
${ }^{46}$ R. Gellately, op. cit., s. 345.

47 Ibidem, s. 29; zob. także hasło: Liebe („miłość”), w: M. Weber, op. cit., s. 120. Na przykład L.L. Rasmussen zauważa, że z początkiem lat czterdziestych, $\mathrm{w}$ trakcie wojny i jej radykalizacji, Bonhoeffer, mówiąc o najwyższym dobru, skupia się na etycznym wymiarze tego określenia, na naśladowaniu (Nachfolge) w sensie bardzo praktycznym: podążaniu za Chrystusem w codzienności III Rzeszy; por. L.L. Rasmussen, Dietrich Bonhoeffer. Reality and Resistance, Louisville 2005, s. 126-127, D. Bonhoeffer, Naśladowanie, tłum. J. Kubaszczyk, Poznań 1997.

48 D. Bonhoeffer, Rechenschaft an der Wende zum Jahr 1943, op. cit., s. 34.

${ }^{49}$ Ibidem, s. 35.

50 Ibidem

51 Ibidem, s. 36.

52 Ibidem, s. 35

53 Zob. B. Beuys, Vergesst uns nicht! Menschen im Widerstand 1933-1945, Reinbek 1985; oraz: R. Gellately, op. cit., s. 284-286.
} 
najczęściej młodych ludzi było stosunkowo wielu, lecz poziom wykrywalności podobnych dysydenckich aktywności był także bardzo wysoki ${ }^{54}$. Dobro (das Wohl) wspólnoty, określanej jako wspólnota narodowa ${ }^{55}$, budowano w oparciu o zbrodniczy system, który wspierano do końca:

W ostatnich dniach III Rzeszy nie brakowało nazistowskich fanatyków, którzy byli zdecydowani walczyć do końca. Wielu było także takich, którzy nie przyjmowali do wiadomości tego, co się stało, i spoglądając na brutalność, nie potrafili zdobyć się na nic innego, jak być po stronie Hitlera, bądź, jak im się wydawało, Niemiec ${ }^{56}$.

\section{Odkrywanie „zakrytego" - rok 1945}

Druga wojna światowa i jej przebieg ujawnily, że Bonhoefferowska „maskarada zła” była jedną z głównych cech tego konfliktu57, który przekształcił Europę w "dziki kontynent" 58 , a bilans zniszczeń, strat i okaleczenia duchowego, jako konsekwencji działań wojennych, był niewyobrażalnie wysoki ${ }^{59}$. Dziesiątego stycznia 1945 roku Armia Czerwona podjęła działania ofensywne, w wyniku których w tydzień później wyzwolono Kraków; po dziewięciu dniach żołnierze jednostek 28 i 106 korpusu I Frontu Ukraińskiego wkroczyli do obozu Auschwitz ${ }^{60}$. Nie było to pierwsze tego typu doświadczenie, gdyż na przykład już pół roku wcześniej, 23 lipca 1944 roku, czerwonoarmiści wkroczyli do obozu koncentracyjnego KL-Lublin, określanego popularnie Majdankiem. Znajdowało się tam jeszcze ponad tysiąc więźniów, którymi zajęły się jednostki Czerwonego Krzyża, a istniejącą strukturę obozową sowieci w trybie pilnym przekształcili w obóz dla żołnierzy AK i NSZ, który po wybuchu powstania w Warszawie szybko zaczął się zapełniać.

Publikując w styczniu 2015 roku, siedemdziesiąt lat po zakończeniu wojny, książkę La Dècouverte („Odkrycie”), jej autorka, Anette Viewiorka61, wykazała dobitnie, jak stopniowo i bardzo powoli prawda o obozach kon-

\footnotetext{
${ }^{54}$ R. Gellately, op. cit., s. 290.

55 S. Keller, Volksgemeinschaft am Ende: Gesellschaft und Gewalt 1944/45, München 2013, s. 8.

56 Ibidem, s. 366.

57 Zob. E. Mawdsley, II wojna światowa. Nowe ujęcie, tłum. B. Gutowska-Nowak, Kraków 2011, s. 453-461; oraz: T. Schramm, Historia wspótczesna, wiek XX, Poznań 2008, s. 98-101.

${ }^{58}$ K. Lowe, Dziki kontynent. Europa po II wojnie światowej, tłum. M.P. Jabłoński, Poznań

${ }^{59}$ T. Schramm, op. cit., s. 99.

${ }^{60}$ D. Dwork, R.J. van Pelt, Auschwitz. Historia miasta i obozu, tłum. K. Bażyńska-Chojnacka, P. Chojnacki, Warszawa 2011, s. 359-360.

${ }^{61}$ A. Viewiorka, 1945. La Dècouverte, Paris 2015, s. 19.
} 2013. 
centracyjnych i zagłady zaczęła docierać do światowej opinii publicznej. Każde $\mathrm{z}$ alianckich państw miało $\mathrm{w}$ tej kwestii odrębny sposób postępowania i zasady, którymi się kierowało. Rosjanom po zajęciu wschodnich terenów Rzeczpospolitej na rękę było niepodnoszenie tej kwestii, gdyż zamierzali na trwałe włączyć Polskę w sferę swoich wpływów. Wyzwolenie przez aliantów obozów w Bergen-Belsen i Buchenwaldzie nieopodal Weimaru w kwietniu 1945 roku $^{62}$ stanowi tu bardzo istotną cezurę - problematyka specyfiki nazistowskiego systemu okupacyjnego stała się, $\mathrm{w}$ rezultacie coraz częstszych przekazów medialnych, obecna jako efekt drugiej wojny światowej, z którym należało się zmierzyć. Jak pisze Tomasz Schramm:

Terror, odczuwalny w życiu codziennym, a spotęgowany w obozach koncentracyjnych (tę uwagę należy w pełni odnieść też należy do obozów japońskich), przyniósł wielu ludziom trwałe okaleczenie nie tylko fizyczne, ale i psychiczne. Było to też swoiste doświadczenie moralno-intelektualne, rozbijające dotychczasowy system wartości i wiarę w kulturę europejską, zwłaszcza że za jednego z głównych jej twórców i nosicieli uważano Niemców ${ }^{63}$.

Zrekonstruowana na podstawie źródeł i skomentowana przez francuską badaczkę podróż żydowskiego dziennikarza Mayera Levina ${ }^{64}$ i fotografa Erica Schwaba65, jaką obaj odbyli w dniach od 5 kwietnia do końca maja 1945 roku, odwiedzając miejsca, w których dopiero co przestały działać nazistowskie obozy w Terezinie, Buchenwaldzie, Dachau i innych miejscowościach ${ }^{66}$, obnażyła to, jak niewyobrażalna była rzeczywista konfrontacja Volksgemeinschaft z rezultatami jej ideologicznych przesłanek.

Przed Niemcami rozpoczęło się zadanie "powrotu do cywilizowanego świata" 67, a jednym z pierwszych kroków, jakie przewidzieli alianci, było przygotowanie procesów sądowych, w których osądzić miano w pierwszym rzędzie najwyższych funkcjonariuszy nazistowskich. Deklaracja moskiewska, sformułowana 1 listopada 1943 roku, przewidywała, że przestępcy wojenni podlegać będą jurysdykcji kraju, na terenie którego popełnili swe zbrodnie, i tam też zostaną osądzeni i poddani karze według prawa, które tam obowiązuje ${ }^{68}$. Kwestią sporną, jak się później okazało, było postawienie

62 Ibidem, s. 29-30.

63 T. Schramm, op. cit., s. 100.

${ }^{64}$ Mayer Levin był dziennikarzem zatrudnionym w żydowskiej agencji informacyjnej, która działała armii amerykańskiej; A. Viewiorka, op. cit., s. 9.

65 Ibidem, s. 8.

66 Ibidem, s. 10-11.

67 Por. K.H. Jarausch, Po Hitlerze. Powrót Niemców do cywilizowanego świata 1945-1995, tłum. M. Serwański, Poznań 2013.

68 J. Heydecker, J. Leeb, Trzecia Rzesza w świetle Norymbergi. Bilans tysiąca lat, tłum. M. Zeller, Warszawa 1979, s. 104. 
przed sądem tych sprawców, których czyny „nie dadzą się zlokalizować pod względem geograficznym" 69 . Ostatecznie, po kilku miesiącach trudnych negocjacji i nacisków ze strony amerykańskiej, 8 sierpnia 1945 roku podpisano tak zwane porozumienie londyńskie przewidujące powstanie Międzynarodowego Trybunału Wojskowego (IMT). Ustalono przebieg samego procesu i jego zasady ${ }^{70}$ :

akt oskarżenia zostaje odczytany na sali sądowej; trybunał pyta każdego oskarżonego, czy przyznaje się do winy, czy się nie przyznaje; oskarżyciele przedstawiają sprawę; trybunał pyta oskarżycieli, jakie dowody mają zamiar przedłożyć, i trybunał postanawia co do dopuszczenia każdego z tych dowodów; najpierw zostaną przesłuchani świadkowie oskarżenia, po nich świadkowie obrony. Z kolei oskarżyciele oraz obrońcy mają prawo powołać środki na odparcie tych dowodów ${ }^{71}$.

Faza przygotowawcza wykazała, iż niekończąca się lista zarzutów wymagała specjalnego podejścia, choć większość Niemców dziwiła się, że świat ich obarcza za zbrodnie nazizmu - nie pojmowali w ogóle immanentnej relacji pomiędzy Volksgemeinschaft a popełnionymi zbrodniami ${ }^{72}$.

W celu udowodnienia zbrodni „trybunał może w każdej chwili zadawać pytania i może zadawać krzyżowe pytania każdemu świadkowi i oskarżonemu, który zeznaje”, następnie "obrona wygłasza przemówienie końcowe”, po niej „oskarżenie wygłasza przemówienie końcowe"73. Każdy z oskarżonych mógł złożyć oświadczenie, po którym miał zostać wygłoszony wyrok z uzasadnieniem.

Aresztowano, internowano, a następnie postawiono przed sądem całą grupę nazistowskich przywódców, którzy, jak marszałek Hermann Göring, zostali przy życiu i dostali się $\mathrm{w}$ ręce aliantów ${ }^{74}$. Alianci rozważali przepro-

${ }^{69}$ Ibidem.

70 Ibidem, s. 111-113.

71 Ibidem, s.112.

72 Por. K. Jarausch, op. cit., s. 26.

73 J. Heydecker, J. Leeb, op. cit., s. 112.

${ }^{74}$ Göring był także naczelnym dowódcą Luftwaffe, przewodniczącym Reichstagu, pełnomocnikiem do spraw planu czteroletniego. Osądzono ponadto ministra spraw zagranicznych Joachima von Ribbentropa; Rudolfa Hessa, byłego zastępcę Führera; Alfreda Rosenberga, określanego głównym ideologiem nazizmu, który był ministrem do spraw okupowanych terytoriów wschodnich; Hansa Franka, ministra bez teki w rządzie Hitlera, potem generalnego gubernatora okupowanych ziem polskich; Wilhelma Fricka, ministra spraw wewnętrznych; Fritza Sauckla, generalnego pełnomocnika do spraw wykorzystania siły roboczej; Alberta Speera, ministra uzbrojenia i amunicji; Hjalmara Schachta, przedwojennego ministra gospodarki i prezesa Banku Rzeszy; Waltera Funka, następcę Schachta w czasie wojny. Przed trybunał doprowadzono też Franza von Papena, byłego kanclerza Rzeszy, w okresie władzy Hitlera ambasadora w Wiedniu i Ankarze; Konstantina von Neuratha, ministra spraw zagranicznych 
wadzenie procesu w Berlinie, jednakże zdecydowano się ostatecznie na Norymbergę, miejsce nazistowskich Parteitagów. Dochodzenie wstępne przeprowadzano $\mathrm{w}$ maleńkim kurorcie Bad Mondorf, położonym niedaleko Luksemburga. Osadzonych zaczął badać także psycholog więzienny, Gustave M. Gilbert ${ }^{75}$, który prowadził szczegółowy notatnik z tych przesłuchań; kontynuował on swą pracę w Norymberdze. Opublikowany w 1947 roku Dziennik Norymberski ${ }^{76}$ Gilberta stanowi bardzo ważny dokument uzupełniający protokół szczegółowy z rozprawy, obejmujący szesnaście tysięcy stron maszynopisu.

\section{Zdejmowanie masek}

Bezmiar nazistowskich zbrodni przekracza wszelkie możliwości ludzkiej wyobraźni i wywołuje w człowieku odrazę, zdziwienie, niedowierzanie. Jak podaje Anette Viewiorka77, uczucia te towarzyszyły obydwu reporterom - Mayerowi Levinowi i Ericowi Schwabowi - niemal bezustannie, stwarzając tak silne napięcie, że o mało co nie doszło do przerwania dokumentacji. Podróż przez kolejne stacje piekła obozowego spowodowała, że doświadczenie naoczności zbrodni, kumulowane przez kilka tygodni, doprowadziło u fotografa do objawów psychosomatycznych i zagrożenia życia.

Amerykanie, widząc, iż większość obywateli Niemiec nie wierzyła w możliwość popełnienia tak straszliwych czynów przez naród, który sam siebie określał mianem cywilizowanego, wypracowali już w kwietniu 1945 roku metodę bezpośredniej konfrontacji Niemców z "laboratorium” zła, z którym często pomieszkiwali, rzec by można, po sąsiedzku. Warto w tym kontekście przypomnieć decyzję amerykańskiej komendantury wojskowej w Weimarze, która przeprowadziła lekcję denazyfikacji w sposób bardzo

w latach 1932-38, stojącego później na czele protektoratu Czech i Moraw. Na ławie oskarżonych zasiedli także: Baldur von Schirach, przywódca młodzieżówki NSDAP, gauleiter w Wiedniu; Artur Seiss-Inguart, kanclerz Austrii, potem komisarz Rzeszy w Holandii; Julius Streicher, gauleiter Frankonii, wydawca tygodnika „Der Stürmer"; Wilhelm Keitel, feldmarszałek, szef naczelnego dowództwa Wehrmachtu; Alfred Jodl, generał, szef sztabu dowodzenia Wermachtu; Karl Dönitz, dowódca sił morskich, mianowany przez Hitlera prezydentem Niemiec i naczelnym dowódcą Wehrmachtu, oraz Hans Fritzsche, szef departamentu radia w Ministerstwie Propagandy. Por. Der Nürnberger Prozess. Das Protokoll des Prozesses gegen die Hauptkriegsverbrecher vor dem internationalen Militärgerichtshof 14 November 1945- 1 Oktober 1946,

CD-Rom, Digitale Bibliothek, Bd. 20, Direct Media Publishing, Berlin 2006.

75 J. Heydecker, J. Leeb, op. cit., s. 113

76 Por. wydanie polskie: G.M. Gilbert, Dziennik Norymberski, tłum. T. Łuczak, Warszawa 2012.

77 A. Viewiorka, op. cit. s. 22-23. 
konkretny, można by dziś rzec - okrutny, lecz pouczający. Nieopodal miasta, w którym zamieszkiwał przez wiele dziesięcioleci Johann Wolfgang von Goethe, naziści urządzili obóz koncentracyjny w Buchenwaldzie. Pod koniec kwietnia 1945, gdy trwały jeszcze działania wojenne, wybrano losowo 1200 mieszkańców Weimaru i urządzono im oprowadzanie po obozie koncentracyjnym, nie szczędząc żadnych szczegółów: „Rozpoczęto od pokazania kawałków ludzkiej skóry, którą przetwarzano w tatuowany pergamin, który miał służyć jako abażur do lamp. «Ludność niemiecka to wszystko zobaczyła i zapłakała. Ci, którzy nie płakali, byli zawstydzeni»"78.

Sformułowany przez Trybunał akt oskarżenia można streścić w czterech zasadniczych punktach: 1 . Oskarżeni stworzyli spisek w celu zdobycia nieograniczonej władzy; 2. Zbrodnie przeciwko pokojowi obejmowały naruszenie trzydziestu sześciu układów międzynarodowych, wywołanie wojny napastniczej i światowej; 3. Zbrodnie wojenne dotyczyły popełnionych rzezi, masowych morderstw, tortur, gospodarki rabunkowej; 4 . Zbrodnie przeciwko ludzkości obejmowały prześladowania przeciwników politycznych, mniejszości narodowych, eksterminację całych grup ludności ${ }^{79}$.

Dwudziestego listopada 1945 roku w Pałacu Sprawiedliwości w Norymberdze rozpoczął się proces, odczytano całość aktu oskarżenia. Dzień później wszyscy oskarżeni "stwierdzili, że są niewinni"80. Do dwudziestego dziewiątego listopada odczytywano różnego rodzaju dokumenty, a oskarżeni wymieniali ze sobą uwagi, komentowali poszczególne słowa, uśmiechali się ${ }^{81}$. Popołudniem tego dnia jeden $\mathrm{z}$ amerykańskich prokuratorów, James Britt Donovan, zapowiedział projekcję filmu dokumentalnego o obozach koncentracyjnych; wówczas „wesołość w ławie oskarżonych nagle ustała" 82 .

Amerykanie rozpoczęli na sali sądowej w Norymberdze tę samą procedurę, co uprzednio w Weimarze, Ohrdruff, Sachsenhausen pod Berlinem i innych miejscach Niemiec. Maskarada się kończyła, należało spojrzeć na ekran filmowy i przyglądać się "paleniu więźniów żywcem w stodole"83. M. Gilbert szczegółowo opisał zachowanie każdego z nazistowskich funkcjonariuszy: „Schacht nie chce patrzeć, odwraca wzrok i spogląda na galerię,

\footnotetext{
${ }^{78}$ K. Jering, Überleben und Neubeginn: Aufzeichnungen eines Deutschen aus dem Jahr 1945/46, München 1979, s. 19-20.

79 J. Heydecker, J. Leeb, op. cit., s. 112.

80 Der Nürnberger Prozess. Das Protokoll des Prozesses gegen die Hauptkriegsverbrecher vor dem internationalen Militärgerichtshof 14 November 1945 - 1 Oktober 1946, CD-Rom, Einführung von Christian Zentner.

${ }^{81}$ G.M. Gilbert, op. cit., s. 55-57.

82 Ibidem, s. 58

83 Nürnberger Prozess. Das Protokoll des Prozesses..., op. cit., 29 November 1945.
} 
Frank próbuje powstrzymać łzy, Göring nie patrzy, wygląda na wpół żywego" 84. Prokuratorzy pokazują filmy z różnych obozów koncentracyjnych: Dachau, Bergen-Belsen itd. Filmy przedstawiają eksperymenty medyczne na więźniarkach, spychacz wrzucający nagie kobiece ciała do masowego gro$\mathrm{bu}^{85}$. Takie projekcje filmowe powtarzano jeszcze kilkakrotnie, za każdym razem wywoływały one u oskarżonych bardzo różne reakcje, czasem płacz, złość lub obojętność.

Zupełnie inne zachowanie towarzyszyło pokazom filmów nazistowskich. Przemówienia Hitlera wzbudzały w ławie oskarżonych pełen entuzjazm, wręcz radość, że mogą go znów zobaczyć; odrealniały one sytuację i prowokowały do pytań o przebieg procesu ${ }^{86}$.

Szokiem dla zebranych było pojawienie na sali sądowej się generała dywizji Erwina Lahousena von Vivremont (1897-1955)87, jedynego pozostałego przy życiu spiskowca, uczestnika zamachu na Hitlera z 20 lipca 1944 roku. Generał Lahousen był świadkiem koronnym dostarczonym w ścisłej tajemnicy do Norymbergi i tam, wraz z innymi świadkami (obrony i oskarżenia), został umieszczony pod dozorem Secret Service w willi na obrzeżach miasta 88 . 30 listopada 1945 roku był pierwszym z trzech dni, w których wypowiadał się człowiek „z wnętrza Volksgemeinschaft”, lecz taki, który przez cały czas współpracował z ruchem oporu i w swoich zeznaniach przed Trybunałem powoływał się na „Das Wohl Deutschlands” - dobro Niemiec ${ }^{89}$. To właśnie psycholog G.M. Gilbert namówił generała na wystąpienie przed sądem w charakterze głównego świadka oskarżenia. To, że Lahousen w ogóle przeżył, było kwestią przypadku: zaraz po 20 lipca 1944 udał się na front, tam ranny przeleżał $\mathrm{w}$ lazarecie kilka tygodni i ślad prowadzący od spiskowców do niego nie został przez SS i Gestapo szczegółowo zbadany90. „Muszę przemówić w imieniu tych, których zamordowaliście” 91 - rzekł Lahousen. Jego zeznania wzbudziły w oskarżonych panikę i wściekłość. Gilbert zanotował w dzienniku niektóre reakcje, np. Göring wykrzyczał: „«Ten zdrajca! To jedyny, o którym zapomnieliśmy dwudziestego lipca. Hitler miał rację - Abwehra była zdradziecką organizacją». [...]. Mówił tak głośno, że

\footnotetext{
${ }^{84}$ M. Gilbert, op. cit., s. 55-57.

85 Nürnberger Prozess. Das Protokoll des Prozesses..., op. cit., 29 November 1945.

86 Ibidem, 11 Dezember 1945.

87 Ibidem, 30 November 1945.

88 Por. Ch. Kohl, Das Zeugenhaus, Nürnberg 1945, München 2014, s. 59-72.

${ }^{89}$ Nürnberger Prozess. Das Protokoll des Prozesses..., op. cit., 30 November 1945.

${ }^{90}$ K. Glaubauf, S. Lahousen, Generalmajor Erwin Lahousen, Edler von Viveremont, Ein Linzer Abwehroffizier im militärischen Widerstand, Berlin - Hamburg - Münster 2005, s. 13-15.

${ }^{91}$ Nürnberger Prozess. Das Protokoll des Prozesses..., op. cit., 30 November 1945.
} 
ewidentnie obwieszczał linię partii"92. Zeznania Lahousena miały, jak się potem okazało, centralne znaczenie dla skazania większości oskarżonych. Szczegółowo opisał on przygotowanie wojny napastniczej na Polskę, wyjaśnił drobiazgowo przebieg wojny na wschodzie, której celem było wyniszczenie milionów istnień ludzkich. Zeznania Lahousena obciążyły nie tylko SS, lecz także i Wermacht, i ukazały całość zbrodniczego systemu. Obrońcy zdecydowali się zaprzestać stawiania świadkowi pytań, gdyż „on rzuci nam w twarz jeszcze większą ilość szkodliwych informacji"93.

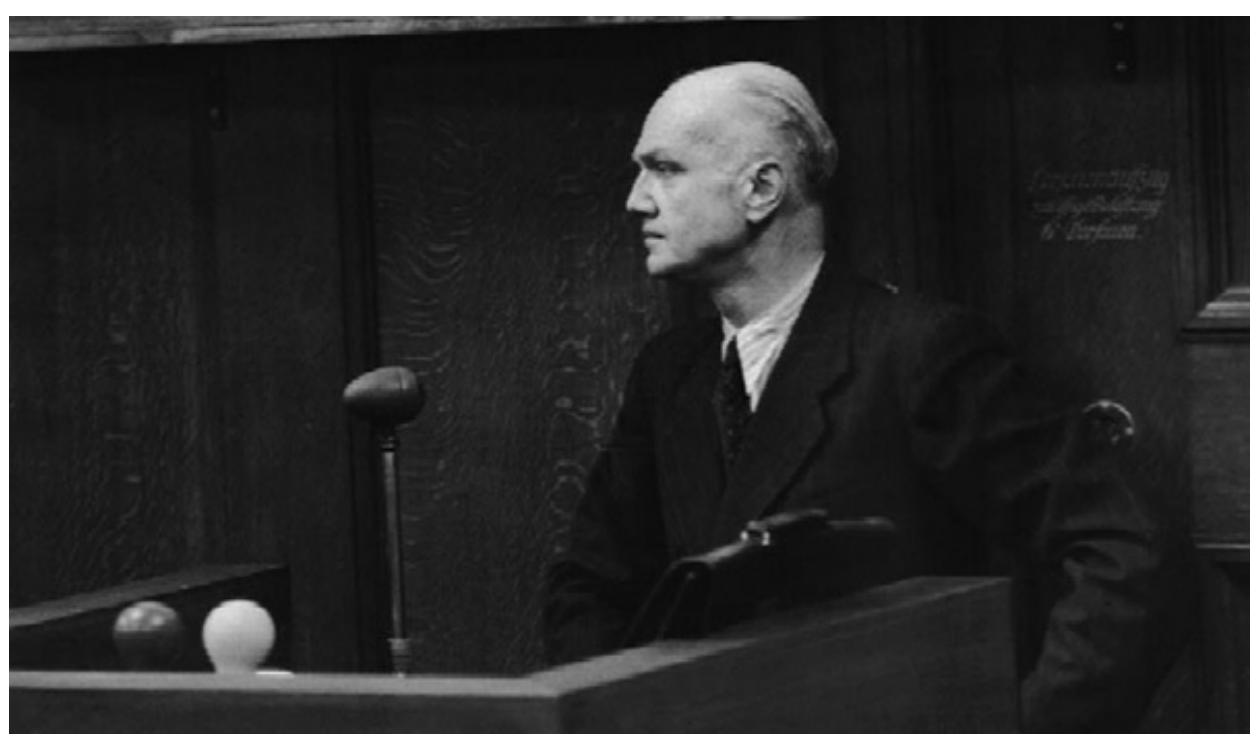

Rys. 1 Generał Erwin Lahousen przed Trybunałem w Norymberdze

(http://img.over-blog-kiwi.com/0/99/13/66/20141025/ob_aa34bc_lahousen-erwinvon.jpg)

Generał Lahousen był przedstawicielem niemieckiego ruchu oporu, o którym wspomniano już wcześniej. Traktowano go później także jak zdrajcę, tego, który pokalał własne gniazdo, poszargał oficerski honor. Bardzo trudno było Niemcom przyzwyczaić się do myśli, że wspólnota narodowa wydała zdrajców, którzy zdecydowali się uśmiercić wodza, za którym stała większość ${ }^{94}$. Jeszcze przez kilka dziesięcioleci po Norymberdze trwał będzie

92.M. Gilbert, op. cit. s. 64 .

${ }^{93}$ Ibidem, s. 65.

${ }^{94} \mathrm{Nie}$ ma tu miejsca na przedstawienie całości tej problematyki i poszczególnych aktorów wydarzeń. Warto jednak prześledzić drogę, jaką po kapitulacji Niemiec w 1945 r. przebyli ludzie, którzy sprzeciwiali się nazistowskiemu systemowi: najpierw określano ich „zdrajcami 
proces „wymuszonej reorientacji”95, który doprowadzić miał stopniowo naród niemiecki do zmiany poglądów i postaw ${ }^{96}$; dodajmy, że do dziś nie jest to proces całkowicie zakończony ${ }^{97}$.

Od końca 1946 roku przewodniczenie zespołowi oskarżycieli przejęli Francuzi. Ich linia oskarżenia była nakierowana całkowicie na prezentacje zeznań osób, które przeżyły obozy koncentracyjne: Majdanek, Mauthausen, Auschwitz, Ravensbrück i inne ${ }^{98}$. Najbardziej szczegółowe zeznania przedstawiła francuska reporterka i deputowana do Zgromadzenia Ustawodawczego, odznaczona Legią Honorową Marie-Claude Vaillant-Couturier (1912-1996). Jako działaczka francuskiego ruchu oporu, została ona w 1943 roku osadzona w Auschwitz, tam także udało się jej kontynuować działalność; następnie przeniesiono ją do Ravensbrück, skąd uwolniła ją, jak i inne kobiety, armia radziecka. Wielogodzinne i bardzo szczegółowe wypowiedzi dawnej więźniarki budziły ogromną niechęć oskarżonych. Nawet i wtedy nie udało się powstrzymać agresji: obrońca Juliusa Streichera, gauleitera Frankonii, adwokat Hans Marx zapytał świadka, jak to się stało, „«że pomimo tego wszystkiego, co Pani przeżyła, dziś jeszcze może do nas mówić». Odpowiedź francuskiej reporterki była bardzo wyważona: «Miałam rok czasu, aby dojść do siebie»" $"$ "

narodu", kalającymi własne gniazdo. Stopniowo i powoli przywracano im historycznie należne miejsce, często jednak był to proces trwający kilka dziesięcioleci, odbywający się kosztem rodziny i krewnych. Ikona oporu, zamachowiec na Hitlera z 20 lipca 1944 roku, Claus Schenk von Stauffenberg traktowany był w powojennej bundeswerze jak persona non grata: „Dlaczego boimy się wspominać i uczcić mężów 20 lipca? Czy dlatego, że takie upamiętnianie naruszy podstawy autorytetu państwa i wojska? Przecież byli to spiskowcy, którzy złamali przysięgę wojskową?"; por. J. Tuchel, Zwischen Diffamierung und Anerkennung: Zum Umgang mit dem 20 Juli in der frühen Bundesrepublik, „Aus Politik und Zeitgeschichte“ 2014, No. 64, Heft 27, s. 18-24, cytat s. 24.

95 K. Jarausch, op. cit., s.47-49.

${ }^{96}$ Jeszcze trudniejsze jest spojrzenie na niektórych bohaterów antynazistowskiego oporu z perspektywy relacji polsko-niemieckich. Claus von Stauffenberg, ",uczestnik kampanii wrześniowej 1939 roku, opisywał w liście do żony mieszkańców Polski, jako «niewiarygodny motłoch», «naród, który aby się dobrze czuć, potrzebuje batoga»"; cyt za: T. Szarota, Moralni zwycięzcy. Refleksje z okazji 60. Rocznicy Powstania Warszawskiego i zamachu pułkownika Stauffenberga na Hitlera, "Dialog” 2004, nr 68, s. 77. Na zaproszenie niemieckiego rządu z okazji 68 rocznicy zamachu wystąpił z przemówieniem dawny ambasador RP w Berlinie Janusz Reiter, wyrażając swój dystans wobec niemieckich bohaterów, którzy byli wrogami Polski. Podobnie rzecz miała się trzy lata później, latem 2015 roku - gdy prezydent RP Bronisław Komorowski miał się udać $\mathrm{z}$ tej okazji do Berlina, nie milkły głosy krytyki zachęcające go do zaniechania wizyty; http://www.sueddeutsche.de/politik/janusz-reiter-zum-stauffenberg-attentatdeutsche -widerstandskaempfer-verachteten-polen-1.1418073 (dostęp 10.05.2015 r.).

97 Por. A. Wolff-Powęska, Pamięć. Brzemię i uwolnienie. Niemcy wobec nazistowskiej przeszłości (1945-2010), Poznań 2011.

98 Nürnberger Prozess. Das Protokoll des Prozesses..., op. cit., 2 Februar 1946.

${ }^{99}$ Ibidem. 


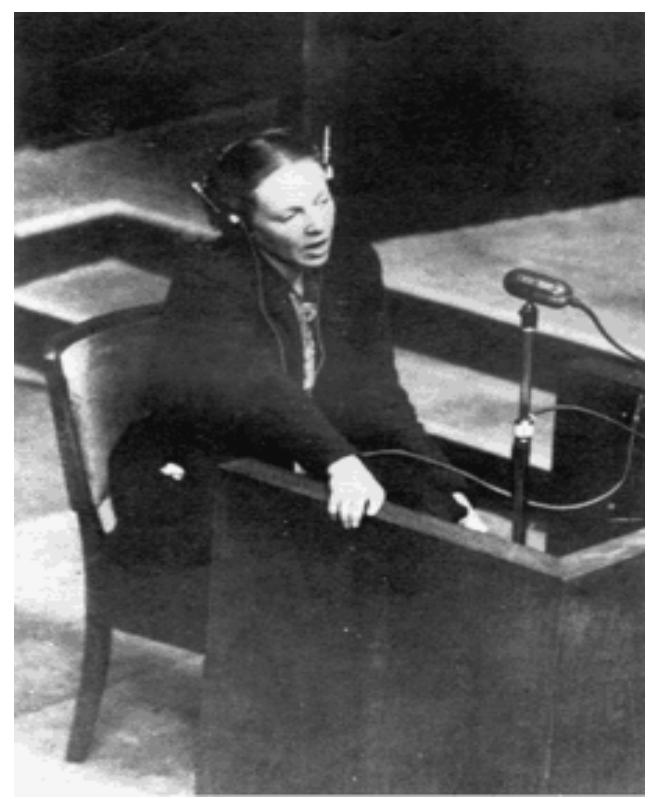

Rys. 2 Marie-Claude Vaillant-Couturier zeznaje przed Trybunałem w Norymberdze (http://www.humanite.fr/sites/default/files/marieclaudevaillantcouturie_0.gif)

I wtedy stało się coś nieoczekiwanego: „Vaillant-Couturier wstała i podeszła do ławy oskarżonych. Powoli i po kolei przyglądała się każdemu z siedzących, zatrzymując wzrok, wpatrywała się każdemu w oczy, lecz większość z nich odwróciła się"100.

W Norymberdze zeznania naocznych świadków trwały tygodniami, kontynuowane były też przesłuchania krzyżowe - sprawdzano wszelkie szczegóły. 31 sierpnia 1946 roku był ostatnim dniem procesu. Większość oskarżonych stwierdziła, że popełniono bestialskie zbrodnie, lecz każdy osobiście działał w dobrej intencji - „dla dobra narodu” (Wohl des Volkes). Na karę śmierci przez powieszenie skazano Martina Bormanna (zaocznie), Hansa Franka, Hermanna Göringa, Alfreda Jodla, Ernsta Kaltenbrunnera, Wilhelma Keitla, Joachima von Ribbentropa, Alfreda Rosenberga, Fritza Sauckla, Arthura Seys-Inquardta oraz Juliusa Streichera. Wyroki wykonano 16 października 1946 roku, Hermann Göring popełnił samobójstwo w swej celi. Inni, jak np. Karl Dönitz, Walter Funk, Baldur von Schirach, Albert Speer, otrzymali kary więzienia od dziesięciu lat do dożywocia. Uniewinniono Franza von Papena i Hjalmara Schachta ${ }^{101}$.

100 Ibidem.

101 J. Heydecker, J. Leeb, op. cit., s. 617. 
Równolegle trwała w Niemczech rozpoczęta kampania naoczności. Cały kraj zalały plakaty pokazujące góry nagich ciał, wygłodniałe twarze oswobodzonych z kacetów. Pojawiały się napisy: „Te czyny haniebne to wasza wina!"102 Niektórzy badacze uważają, że przyczyniło się to do jeszcze większej blokady $\mathrm{w}$ niemieckim społeczeństwie, ale ostatecznie trudno powiedzieć, na ile przesunęło to $\mathrm{w}$ czasie otwarcie się wojennej generacji na powrót „wypartego", który nastąpił wraz z kolejną zmianą pokoleniową ${ }^{103}$.

W 2012 roku Janusz Reiter stwierdził w swoim przemówieniu, iż Dietrich Bonhoeffer był $\mathrm{w}$ Polsce autorytetem dla wielu104. Obecne $\mathrm{u}$ tego ewangelickiego teologa specyficznie pojmowane, transcendentne rozumienie dobra, jego prawdziwe wyczucie i przylgnięcie do Absolutu uczyniło go postacią rozpoznawalną $\mathrm{w}$ krajach niemieckojęzycznych i anglosaskich już zaraz po wojnie. W swej rozprawie doktorskiej Ewa Łepkowska ukazała świat wartości, którymi kierował się Bonhoffer, oraz wpływ, jaki jego postać miała na kształtowanie się opozycji demokratycznej PRL-u'105, która odbudowywała kraj od wewnątrz, starając się uniknąć „maskarady zła”.

\section{Being Good in Third Reisch - a Preliminary Concideration}

Summary

Speaking on good in context of Third Reich is a big challenge for a scholar. Realities of German national community - as projected and actualized by Nazis - which based on total exclusion (including physical extermination) of some ethic groups, causes that in order to find something or someone what/who was good there, one needs to refer to statements of the people who took exception to the system and stayed beyond it or on its rim. In this article authoress focuses on Dietrich Bonhoeffer's diaries, where author depicts years 1936-1942 spent on conspiracy, and chosen documents from Nuremberg trials which reveals enormity of crime made by Nazi system.

102 Por. B. Wollbring: Nationales Stigma und persönliche Schuld. Die Debatte über Kollektivschuld in der Nachkriegszeit, „Historische Zeitschrift” 2009, No. 289, s. 325-364.

${ }^{103}$ Ibidem, s. 332.

104 http://www.sueddeutsche.de/politik/janusz-reiter-zum-stauffenberg-attentat-deutschewiderstandskaempfer-verachteten-polen-1.1418073 (dostęp 10.05.2015 r.)

105 E. Łepkowska, Życie i myśl Dietricha Bonhoeffera w dyskursie opozycjonistów w PRL, rozprawa doktorska napisana pod kierunkiem prof. dr hab. A. Wirpszy, Uniwersytet Warszawski, Instytut Lingwistyki Stosowanej, Warszawa 2011 (maszynopis udostępniony przez autorkę). 